\title{
The diabetes-related attitudes of health care professionals and persons with diabetes in Argentina
}

\author{
Juan J. Gagliardino, ${ }^{1}$ Claudio González, ${ }^{1}$ Joaquín E. Caporale, ${ }^{1}$ \\ and the Diabetes Education Study Group of Argentina ${ }^{2}$
}

Suggested citation

Gagliardino JJ, González C, Caporale JE, Diabetes Education Study Group of Argentina. The diabetesrelated attitudes of health care professionals and persons with diabetes in Argentina. Rev Panam Salud Publica. 2007;22(5):304-7.

ABSTRACT Objective. To test diabetes-related attitudes of health care team members (HCTMs) and people with diabetes in a developing country, in this case, Argentina.

Methods. The third version of the Diabetes Attitudes Scale (DAS-3) was randomly administered, in person, to 252 HCTMs (nurses, nutritionists, physicians, podiatrists, and social workers) and 279 people with type 1 or type 2 diabetes mellitus in several provinces of Argentina in 2004. Data from 531 completed questionnaires were included in the study. The data were statistically analyzed using analysis of variance, covariance, chi-square, and $\mathrm{t}$-tests.

Results. Although few, the differences in attitudes of HCTMs and people with diabetes were significant. The two groups expressed only slight agreement on DAS-3 statements such as "seriousness of type 2 diabetes," "value of tight control," and "psychosocial impact of diabetes;" and disagreed completely on "patient autonomy." No significant differences were recorded between people with type 1 or type 2 diabetes regarding "seriousness of the disease," but from both groups, those individuals who had previously attended a diabetes education course assigned this statement a higher score $(\mathrm{P}<0.01)$.

Conclusions. The unfavorable trend among the participants, similar to that recorded in developed countries, would contribute to the poor treatment outcomes observed in people with type 2 diabetes. Changing these attitudes by means of education could contribute to improving the quality of care and of life for people with diabetes and to decreasing the cost of the disease.

Key words Diabetes mellitus; health knowledge, attitude, practice; patient care team; self care; Argentina.

Center of Experimental and Applied Endocrinology (CENEXA-PAHO/WHO Collaborating Center for Diabetes Research, Education, and Care) and National Council on Scientific and Technical Research (CONICET), National University of La Plata, La Plata, Argentina. Send correspondence to: Juan José Gagliardino, CENEXA (UNLP, CONICET), Facultad de Ciencias Médicas, Calles 60 y 120, (1900) La Plata, Argentina; telephone: +54 221 423-6712; fax: +54 221 422-2081; e-mail: direccion@cenexa.org.ar.

2 Mirta Centeno, Patricia Chalabe, María Charadío, Víctor Commendatore, Silvia Lapertosa, Guillermo Marcucci, Víctor Previtera, Rosa L. Raineri, Graciela Rubin, María O. Szykowsky, and Mirta Villagra.
Although the chronic complications of diabetes can be effectively prevented or delayed (1-4), most people with diabetes still suffer from them. Poor quality of diabetes care may be responsible for the disconnect between scientific knowledge and real world results. In fact, the quality of care frequently falls far short of the standards recommended by the American Diabetes Association (5) and what is considered "optimal" care in the United
States of America (6), as well as in countries in Latin America (7). It has been shown that poor diabetes care is partly due to the prevalent, misguided attitudes of both health care providers and people with diabetes (8). Alternatively, patients who report high levels of adherence to diabetes care and control have more positive attitudes toward disease management (9). Since these conclusions were obtained mainly from studies in developed 
countries, they could not be strictly applied to developing countries where the health scenario can be quite different. Therefore, a diabetes-related attitudes study in a developing country was needed. Based on this need and the assumption that the study would explain the poor results of diabetes treatment in Argentina (10) and help define appropriate strategies for overcoming the issues identified, we surveyed health care team members (HCTMs) and people with diabetes. The questionnaire employed for the survey was the third version of the Diabetes Attitudes Scale (DAS-3) (11).

\section{MATERIALS AND METHODS}

In 2003, the Diabetes Education Study Group of Argentina (DESGA) decided to evaluate diabetes-related attitudes of HCTMs and people with diabetes. Eleven of the 15 DESGA members, each with extensive experience in diabetes treatment and control and with numerous diabetes patients, participated in the study.

The evaluation tool, DAS-3, has improved internal reliability scores and is shorter than earlier versions, thus becoming a valid and reliable tool to measure diabetes-related attitudes. Further, it is suitable for performing comparisons across different groups, i.e. HCTM and/or people with diabetes. DAS-3 includes 33 statements that by different combinations are resolved into five discrete subscales, namely, attitude toward (1) need for special training to provide diabetes care, (2) seriousness of type 2 diabetes, (3) value of tight glucose control, (4) psychosocial impact of diabetes, and (5) patient autonomy. Each subscale is classified according to the following possible scores: strongly agree $=5$, agree $=4$, neutral $=3$, disagree $=2$, and strongly disagree $=1$. Consequently, while a score of 3 indicates almost no clear definition, values above or below represent agreement or disagreement with the corresponding statement of the subscale. DAS-3 was translated into Spanish, with the permission of Dr. Anderson, and validated in our population (Cronbach's $\alpha$-coefficient 0.987 , unpublished ${ }^{3}$ ) before its implementation.

Eleven DESGA members personally and sequentially delivered approximately 50 DAS-3 questionnaires each to HCTMs and people with diabetes (simple access order), within their respective organizations, along with an explanation of the study aims. The completed surveys were collected, preserving the anonymity of those surveyed. Diabetes type was defined by the patient's clinical records. Since members of the DESGA belong to different regions of the country and work in different health sectors (Public Health, Social Security, and Prepaid System), data were collected from all three health sectors.

From a total of 542 questionnaires distributed, 531 (98\%) were collected from 252 HCTMs (46\% physicians, $27 \%$ nurses, $12 \%$ nutritionists, $7 \%$ social workers, $3 \%$ podiatrists, $5 \%$ educators), and 279 people with diabetes. Thirty-two percent of the patients had type 1 diabetes and the remaining $68 \%$ had type 2 diabetes. This percentage does not correspond to the low values of people with type 1 diabetes described in the adult general population, however, similar figures to ours were found in diabetes-treated population databases $(7,12)$. This difference is due to the large number of people with type 2 diabetes who ignore their disease and to those who know it but do not receive any type of treatment, while the opposite situation occurs among people with type 1 diabetes (13). Thirty percent of the patients had previously attended structured, educational diabetes courses.

The data collected were statistically evaluated using ANOVA, covariance, and $t$-test.

\section{RESULTS}

Table 1 summarizes the characteristics of the population sample. Most

\footnotetext{
3 We have evaluated the internal consistency of the DAS-3 in a population of HCTMs and diabetic patients with similar characteristics of those studied here in two hospitals of our country $(n \approx 160)$. The results are available upon request from the authors.
}

HCTMs worked in the public sector and were physicians. The predominant form of diabetes was type 2 .

Results of the survey (Table 2) are quite striking. Scales whose importance has strong reported evidence such as "seriousness of type 2 diabetes," "value of tight control," and "psychosocial impact of diabetes," received only a slight agreement from the participants (borderline to the neutral level of 3); it was even worse for "patient autonomy." In the case of "patient autonomy," neither HCTMs nor people with diabetes considered it an important issue (score below neutral level of 3).

Although initially we conducted separate evaluations of the data collected from the different types of HCTMs, we finally analyzed all data together because no significant differences were recorded among those subgroups when comparing the different scale items. Conversely, when we analyzed the data collected from HCTMs in Argentina's different health care sectors, professionals working in the public health sector generally had lower scores than those of the prepaid sector $(P<0.05)$.

We recorded no significant differences between people with type 1 or type 2 diabetes, but those who had previously attended diabetes education courses had higher scores regarding "seriousness of the disease" $(P<$ $0.01)$. There were significant differences between HCTMs and people with diabetes at scales 1, 2, and 5. In the first two scales, HCTMs recorded higher score values, while the opposite occurred with "patient autonomy."

\section{DISCUSSION}

Our results show that among the study population (HCTMs and people with diabetes in the different health care sectors of a developing country), attitudes toward different aspects of type 2 diabetes are not exactly the same. A similar difference was previously recorded by other authors and in different health settings using the DAS-1 (14) and DAS-3 (15). This statistical difference between the two groups would not have the same sig- 
TABLE 1. Demographic characteristics of health care team members (HCTMs) and people with diabetes, Argentina, 2004

\begin{tabular}{lcccc}
\hline & $\begin{array}{c}\text { Age } \\
(\text { mean } \pm \text { SD) }\end{array}$ & $\begin{array}{c}\text { Female } \\
(\%)\end{array}$ & $\begin{array}{c}\text { Public sector } \\
(\%)\end{array}$ & $\begin{array}{c}\text { Prepaid sector } \\
(\%)\end{array}$ \\
\hline HCTMs & & & & \\
$\quad$ Physicians & $42 \pm 13$ & 50 & 86 & 27 \\
$\quad$ Nurses & $43 \pm 8$ & 73 & 70 & 15 \\
$\quad$ Nutritionists & $40 \pm 14$ & 78 & 61 & - \\
Social workers & $40 \pm 4$ & 100 & 67 & - \\
$\quad$ Podiatrists & $48 \pm 15$ & 56 & 89 & - \\
People with diabetes & $39 \pm 17$ & 55 & - & - \\
$\quad$ Type 1 & $38 \pm 18$ & 49 & - & - \\
$\quad$ Educated, ${ }^{\text {b type 1 }}$ & $58 \pm 11$ & 59 & - & - \\
Type 2 & $59 \pm 9$ & 68 & - & \\
Educated, ${ }^{b}$ type 2 & & & & - \\
\hline
\end{tabular}

a Data are means \pm standard deviation.

${ }^{\mathrm{b}}$ Attended educational intervention/course for diabetes.

TABLE 2. Mean DAS-3 scales scores between health care team members (HCTMs) and people with diabetes, Argentina, 2004

\begin{tabular}{lccr}
\hline \multicolumn{1}{c}{ Scale name } & HCTMs $^{\mathrm{a}}$ & People with diabetes $^{\mathrm{a}}$ & $P$ value \\
\hline 1. Need for special training & $4.58 \pm 0.35$ & $4.42 \pm 0.48$ & $<0.01$ \\
2. Seriousness of type 2 diabetes & $3.80 \pm 0.54$ & $3.64 \pm 0.55$ & $<0.01$ \\
3. Value of tight control & $3.50 \pm 0.38$ & $3.49 \pm 0.38$ & $\mathrm{NS}$ \\
4. Psychosocial impact of diabetes & $3.29 \pm 0.46$ & $3.27 \pm 0.56$ & $\mathrm{NS}$ \\
5. Patient autonomy & $2.79 \pm 0.38$ & $2.86 \pm 0.38$ & $<0.05$ \\
\hline
\end{tabular}

a Data are means \pm standard deviation.

nificance or impact from the clinical point of view; in fact, both groups showed a close decreasing trend in the subscale scores, with low agreement values in the items "seriousness of type 2 diabetes" and "value of tight control," and disagreement with regard to "patient autonomy." Such a trend represents a clear misconception considering the strong available evidence on the highly negative socioeconomic impact of type 2 diabetes and the positive preventive effect of blood glucose control (1-4, 16-19). Similar consideration is merited by the low importance given to the role of patient participation, patient-provider consensus on treatment goals, and specific strategies designed to meet the goals and to improve patient outcomes (20-25). This miscon- ception does not represent a minor point considering that type 2 diabetes is the predominant form of the disease in the general population, as well as in the diabetes-treated population. Since in most cases, patients are informed by their physicians about the characteristics of their disease, our results could reflect the negative influence of HCTMs on patient attitudes rather than a merely casual fact.

All in all, these attitudes could be partly responsible for the poor quality of care received by people with type 2 diabetes in Argentina (10), as well as in other countries. Consequently, it is crucial to identify and correct the attitudes of HCTMs toward the "seriousness of type 2 diabetes" and among people with diabetes, attitudes toward "keeping a tight control of the disease" and the value of "patient autonomy." Appropriate interventions for the redirection of such attitudes must be implemented.

Evidence in the literature shows that education is a useful tool for achieving better results in diabetes care quality, namely: (1) continuing medical and patient education not only improves diabetes knowledge but also attitudes toward the disease $(14,22)$; (2) in Argentina, the implementation of a diabetes education program for general practitioners significantly improved their diabetes-related knowledge and prescriptive attitudes, leading to a parallel improvement of clinical and biochemical indicators of care quality (26); and (3) a similar reported improvement was obtained with the implementation of a patient education program for people with type 2 diabetes in 10 Latin American countries (27), as well as in other countries (20-25).

On account of these results and of the low technological level required, a wide implementation of diabetes education programs for both HCTMs and people with diabetes would be an efficient tool for improving the quality of care and decreasing disease costs in both developed and developing countries. Thus, health decision makers, particularly those from developing countries where economic resources are frequently scarce, should be aware of these results and seriously consider the benefits of testing health provider and consumer attitudes, and of incorporating education as part of diabetes care, not only for economic reasons, but also for the quality of life of people with diabetes.

Acknowledgments. The authors are grateful to Adriana Di Maggio for careful assistance in manuscript preparation. This work was funded by CONICET and Novo Nordisk Argentina.

\section{REFERENCES}

1. The effect of intensive treatment of diabetes on the development and progression of long term complications in insulin-dependent diabetes mellitus. The Diabetes Control and
Complications Trial Research Group. N Engl J Med. 1993;329:977-86.

2. Intensive blood-glucose control with sulphonylureas or insulin compared with conven- tional treatment and risk of complications in patients with type 2 diabetes (UKPDS 33). UK Prospective Diabetes Study (UKPDS) Group. Lancet. 1998;352:837-53. 
3. UK Prospective Diabetes Study Group. Tight blood pressure control and risk of macrovascular and microvascular complications in type 2 diabetes (UKPDS 38). BMJ 1998;317: 703-13.

4. Gaede P, Vedel P, Larsen N, Jensen GV, Parving $\mathrm{HH}$, Pedersen O. Multifactorial intervention and cardiovascular disease in patients with type 2 diabetes. N Engl J Med. 2003;348: 383-93.

5. American Diabetes Association. Clinical practice recommendations. Diabetes Care. 2007; 30(Suppl 1):S1-103.

6. McGlynn EA, Asch SM, Adams J, Keesey J, Hicks J, DeCristofaro A, et al. The quality of health care delivered to adults in the United States. N Engl J Med. 2003;348:2635-45.

7. Gagliardino JJ, De La Hera M, Siri F, Grupo de Investigación de la Red QUALIDIAB. Evaluación de la calidad de la asistencia al paciente diabético en América Latina. Rev Panam Salud Pública. 2001;10:309-17.

8. Weinberger M, Cohen SJ, Mazzuca SA. The role of physicians' knowledge and attitudes in effective diabetes management. Soc Sci Med. 1984;19:965-69.

9. Anderson RM, Fitzgerald JT, Oh MS. The relationship between diabetes-related attitudes and patients' self-reported adherence. Diabetes Educ. 1993;19:287-92.

10. Gagliardino JJ, De La Hera M, Siri F. Evaluación preliminar de la calidad de atención de personas con diabetes en Argentina. Rev Soc Arg Diabetes. 2001;35: 121-33.

11. Anderson RM, Fitzgerald JT, Funnell MM, Gruppen LD. The third version of the Diabetes Attitude Scale. Diabetes Care. 1998;21: 1403-7.

12. Gagliardino JJ, Olivera E, Etchegoyen GS, Guidi ML, Caporale JE, Martella A, et al. PROPAT: A study to improve the quality and reduce the cost of diabetes care. Diabetes Res Clin Pract. 2006;72:284-91.
13. Gagliardino J, Olivera E. The regions and their health care systems: Latin American. In: Economics of Diabetes and Diabetes Care. A report of the Diabetes Health Economics Study Group. Gruber W, Lander T, Leese B, Songer T, Williams H, Eds. 1997;51-9.

14. Sharp LK, Lipsky MS. The short-term impact of continuing medical education program on providers' attitudes toward treating diabetes. Diabetes Care. 1999;22:1929-32.

15. Clark M, Hampson SE. Comparison of patients' and healthcare professionals' beliefs about and attitudes towards type 2 diabetes. Diabetic Med. 2003;20:152-4.

16. Gray A, Raikou M, McGuire A, Fenn P, Stevens R, Cull C, et al. Cost effectiveness of an intensive blood glucose control policy inn patients with type 2 diabetes: economic analysis alongside randomized controlled trial (UKPDS 41). United Kingdom Prospective Diabetes Study Group. BMJ. 2000;320:1373-8.

17. Gray A, Clarke P, Farmer A, Holman R United Kingdom Prospective Diabetes Study Group. Implementing intensive control of blood glucose concentration and blood pressure in type 2 diabetes in England: cost analysis (UKPDS 63). BMJ. 2002;325:860.

18. Klonoff DC, Schwartz DM. An economic analysis of interventions for diabetes. Diabetes Care. 2000;23:390-404.

19. CDC Diabetes Cost-effectiveness Group. Cost-effectiveness of intensive glycemic control, intensified hypertension control, and serum cholesterol level reduction for type 2 diabetes. JAMA. 2002;287:2542-51.

20. Muhlhauser I, Berger M. Patient educationevaluation of a complex intervention. Diabetologia. 2002;45:1723-33.

21. Heisler M, Vijan S, Anderson RM, Ubel PA Bernstein SJ, Hofer TP. When do patients and their physicians agree on diabetes treatment goals and strategies, and what difference does it make? J Gen Intern Med. 2003;18:893-902.

22. De Berardis G, Pellegrini F, Franciosi M, Belfiglio M, Di Nardo B, Greenfield S et al.; QuED Study. Physician attitudes toward foot care education and foot examination and their correlation with patient practice. Diabetes Care. 2004; 27:286-7.

23. Pavlic-Renar I, Metelko Z. Effects of an empowerment-based psychosocial intervention on quality of life and metabolic control in type 2 diabetic patients. Patient Educ Couns. 2004; 52:193-9.

24. Funnell MM, Kruger DF, Spencer M. Selfmanagement support for insulin therapy in type 2 diabetes. Diabetes Educ. 2004;30: 274-80.

25. Philis-Tsimikas A, Walker C, Rivard L, Talavera $G$, Reimann JO, Salmon M, Araujo R; Project Dulce. Improvement in diabetes care of underinsured patients enrolled in project dulce: a community-based, culturally appropriate, nurse case management and peer education diabetes care model. Diabetes Care. 2004;27:110-5

26. Gagliardino JJ, Jadzinsky MN, Alvariñas JH, Fabiano A, de Sereday M, Sinay IR. Training program for general practitioners (PROCAMEG): Preliminary results, Diabetes Res Clin Practice. 2000;50(Suppl.2):1

27. Gagliardino J, Etchegoyen G; PEDNID-LA Research Group. A model education program for people with type 2 diabetes: a cooperative Latin-American implementation study. Diabetes Care. 2001;24:1001-7.

Manuscript received on 8 March 2006. Revised version accepted for publication on 28 June 2007.

RESUMEN Objetivo. Analizar las actitudes relacionadas con la diabetes en los miembros del equipo de salud (MES) y las personas con diabetes en un país en desarrollo, Argentina. Métodos. Se administró de forma aleatoria la tercera versión de la Escala de Actitu-

Actitudes relacionadas con la diabetes en los profesionales sanitarios y las personas con diabetes en Argentina des en la Diabetes (DAS-3) a 252 MES (enfermeros, nutriólogos, médicos, podólogos y trabajadores sociales) y a 279 personas con diabetes mellitus tipos 1 ó 2 en varias provincias de Argentina en 2004. Los datos de 531 cuestionarios respondidos se evaluaron mediante análisis de varianza y covarianza, y las pruebas de la $t$ y de la ji al cuadrado. Resultados. Aunque pocas, las diferencias entre las actitudes de los MES y de las personas con diabetes fueron significativas. Los dos grupos mostraron solamente una ligera coincidencia en algunos aspectos del DAS-3, como "importancia de la diabetes tipo 2", "el valor de un riguroso control" y "el impacto psicosocial de la diabetes" y difirieron totalmente en cuanto a "la autonomía del paciente". No se encontraron diferencias significativas entre los pacientes con diabetes tipos 1 y 2 en cuanto a "importancia de la diabetes", sin embargo, en ambos grupos las personas que habían asistido a algún curso educativo sobre diabetes le asignaron una mayor puntuación a este aspecto $(P<0,01)$.

Conclusiones. La tendencia desfavorable encontrada en los participantes de este estudio, similar a la observada en otros países en desarrollo, puede haber contribuido a los insatisfactorios resultados del tratamiento en las personas con diabetes tipo 2 . Cambiar estas actitudes mediante la educación puede ayudar a mejorar la calidad de la atención y de la vida de los diabéticos y a reducir los costos de esta enfermedad.

Palabras clave Diabetes mellitus; conocimientos, actitudes y práctica en salud; grupo de atención al paciente; autocuidado, Argentina. 